\title{
The Implementation of Women Empowerment Policy on Prevention of Violence in Household in Kampar
}

\author{
Emilda Firdaus ${ }^{1}$ \\ \{Emilda27.ef@gmail.com ${ }^{1}$ \} \\ Faculty of Law UNRI Jl. Patimura No.9 Pekanbaru ${ }^{1}$
}

\begin{abstract}
UU PKDRT is a government policy to protect women's rights. During this time women victims of domestic violence shackled with a wrong understanding of religion and culture. This study examines the implementation of women's empowerment policy in the handling of domestic violence in Kampar regency, its inhibiting factors and its prevention efforts. This research is sociological juridical by using primary data. In conclusion, the implementation of women's empowerment policy in coping domestic violence in Kampar Regency still encountered many problems, it is needed a policy in the form of PERDA which is accompanied by empowerment of women in economy sector in accordance with local wisdom of Kampar society.
\end{abstract}

Keywords: Implementation, Empowerment, Domestic Violence.

\section{Introduction}

Discrimination against women that led to the occurrence of violence against women has become a hot issue in recent years. The world community realizes that violence against women is more prevalent in the domestic realm than in the public sphere, after much data and research have revealed it. Violence committed by husbands against their wives can occur in various forms such as physical violence, psychic violence, sexual violence and family neglect. In Indonesia, it is known as domestic violence (hereinafter abbreviated as KDRT).

From the perspective of human rights, discrimination violates human rights. While discrimination against women violates women's rights, so that women empowerment is needed so that women can fight for their rights which are violated. Women's empowerment and the achievement of gender equality are issues of human rights and social injustice and are mistakenly perceived as women's issues alone, as these social conditions and conditions are a requirement in the process of equitable community development and sustainable people's welfare. Therefore, the women's rights struggle which is a growing interaction between individuals with various educational backgrounds, professions and nationalities, the women's movement at national and international levels, has been widely supported by the United Nations over the last 50 years, so the need for equivalent partnership with men or gender equality has become a central issue in the fourth world conference on Women in Beijing, China (1995).

The Universal Declaration of Human Rights is a common standard for increasing respect for human rights and freedoms to be more dignified and protected, based on justice, freedom and peace. After the Universal Declaration of Human Rights, the various international human rights instruments governing the status of women in family and community life, such as the 
Convention on the Elimination of All Forms of Discrimination against Women, are called the Women's Convention or the Convention of Women or the Cedaw Convention, which was born on December 18, 1979. The Cedaw Convention is the Convention the most comprehensive regulating the protection of women's rights, emphasizing the importance of eliminating discrimination against women in all its forms and manifestations. The concept of discrimination is contained in Article $1^{1}$. Another legal instrument governing the status of women is the 1993 Declaration on the Elimination of Violence against Women.

Movement and dissemination of Human Rights continues even by penetrating the territorial boundaries of a country. As soon as the human rights and human rights urges, if any country is identified as violating human rights, the nation-state in this part of the globe has responded, especially to some countries dubbed as 'superpower', criticizing, accusing, even harsh critics such as embargoes and so on.

The Government of Indonesia continues to issue policies to improve the legal system to be more gender-responsive, one of them by issuing laws that are more friendly to the interests of women. However, the values that discriminate against women who have long been rooted in Indonesian society are one of the obstacles to development in the field of women's protection and empowerment, such as patriarchal culture, domestic violence that is considered a family disgrace and so on. This causes women to lose more access to voice their basic rights as human beings.

In addition to having a constitutional basis, the abolition of violence against women has also been regulated by the Law of the Republic of Indonesia Number 23 of 2004 on the Elimination of Domestic Violence (hereinafter referred to as UU PKDRT). UU PKDRT is a real progress generated by the struggle of feminist movement in Indonesia. Domestic violence that has been considered only within private territory has now been made a public problem. In this case the public-private dichotomy has been successfully deconstructed.

Domestic Violence indicates that this form of violence is closely linked to gender issues, discrimination against women and the strength of the culture adopted by the community that household issues are a private matter and only an excess of the dynamics of domestic life.

In the beginning, violence against women is not the same as other conventional crimes, it is not placed as a characteristic crime that is the specification on the victim with female gender and also has a distinctive impact, either specifically on the victim self or in general on social aspect of society. Moreover, there is not even a special treatment for women as victims who are affected by the violent behavior that befell him. Now the law is more responsive and accommodative to the development of understanding the complexity of the forms and impacts of crimes directed at women as victims, thus known as violence against women.

\footnotetext{
${ }^{1}$ Tapi Omas Ihromi dkk( ed). (2006) Penghapusan Diskriminasi Terhadap Wanita. Bandung. PT Alumni. P. 7

CEDAW is actually an abbreviation of the Committee on the Elimination of Discrimination Against Women, a UN committee that oversees the implementation of the Convention on the Elimination of All Forms of Discrimination Against Women in States Parties (States that ratify the Convention) and oversees the compliance of those States in the implementation of the Convention on Women. Article 1, Convention on the Elimination of All Forms of Discrimination Against Women (Cedaw), reads: For the purposes of the present Convention, the term "discrimination against women" means any distinction, exclusion or restriction made on the basis of sex, which has the effect or purpose of reduce or eliminate the recognition, enjoyment or use of human rights and fundamental freedoms in the political, economic, social, cultural, civil or any other field by women, irrespective of their marital status, on the basis of equality between men and women
} 
In the case of violence by the perpetrator, it turns out that the relationship of love and trust is often a myth only. Reports are coming from around the world note that domestic violence occurs in all walks of life. Perpetrators and victims come from various tribes, races, religions, social classes and any level of education.

Socio-cultural values that marginalize and subordinate women also exacerbate this condition. The subordinated relationships are experienced by women all over the world because sub-ordination relationships are not only experienced by developing societies such as Indonesian society, but also experienced by developed countries such as the United States and others. The condition of poverty experienced by women is not due to the fact that women are more lazy than men, but the poverty of women is caused more by structural factors that hegemonies and bind women's roles, so that women's position becomes weak and poor. Besides, there is also a change in the morals and morals of society. The prominent influence of industrialization lies in the status of work and work skills, of the family life and position of women, and the traditions and customs of consuming goods.

Traditional attitudes that women are perceived as male subordination, the stereotyping of stereotyped roles, coupled with traditional female attitudes such as social and economic dependence on husbands and families and the fear and reluctance of women victims of violence to obtain justice, are the main causes among many other causes that cause violence in the household is not revealed or not addressed. Traditional attitudes that assume that what happens in the household are the things that should be resolved in the household as well. Accompanied by the limitations of legislation that can be used to resolve domestic violence through legal channels, from the tortuous reporting process, investigation and investigation process and court application, and court proceedings are also causes why not many victims complain to law enforcement. Still the scarcity of women's crisis centers and the victims' ignorance about the institutions that can help her solve her problems is also the reason that the victim chose to silence her.

In Indonesia, the level of violence against women in households is increasing every year, it turns out that the law products that prohibit violence against women in the household are less strong with the legal culture that has been adopted by the community. Patriarchal culture is one factor that fosters cases of domestic violence.

Riau Province is one of the provinces that is very strategic and has quite a lot of potential natural resources, such as mining, agriculture and fisheries. But recently Riau is again highlighted by events related to domestic violence, this can be seen from data P2TP2A Riau Province, from 2011 to 2016, from 96 cases to 646 cases, or if grouped into 17 case groups. The case of domestic violence is the highest case, in 5 (five) years reached 249 victims, with 55 people in 2013, 44 people in 2014, and 53 people in 2016, this is what causes Riau as a red zone.

The increase of this case cannot be separated from the public's courage to report it, so that the government through the agency or related bodies can well provide services to the community in creating protection. In addition, the data are also inseparable from the coordination or report of the districts in Riau, with Pekanbaru City 431 cases for 5 (five) years, Kampar 100 cases in 3 (three) years, Meranti and Indragiri Islands Downstream with 5 (five) cases each.

The emergence of domestic violence every year as if describing is not maximal preventive measures and protection to women, or how to empower women so that women do not become weak, or become the object of male violence. The protection of women is absolute, as a basis for upholding human rights, which cannot be usurped by anyone and is the responsibility of the State as a consequence of the State of Law. Data on the number of cases of violence 
against women and children who have been reported and followed up by the Kampar District Police Reskrim Unit, in the last 3 (three) years are:

Table 1. Recapitulation of Number of Violence Cases in Women and Children At Kampar Reskrim Unit 2014- 2016

\begin{tabular}{|l|l|l|l|l|l|l|l|l|}
\hline \multirow{2}{*}{ No } & \multirow{2}{*}{ Type of Case } & \multicolumn{3}{|c|}{ Number of Complaints } & \multicolumn{3}{c|}{$\begin{array}{l}\text { Number of Complaints } \\
\text { Under the Follow up }\end{array}$} \\
\cline { 3 - 10 } & & 2014 & 2015 & 2016 & 2014 & 2015 & 2016 \\
\hline 1 & Fornication & 13 & 20 & 18 & 13 & 20 & 18 \\
\hline 2 & Domestic Violence & 7 & 14 & 8 & 7 & 14 & 8 \\
\hline 3 & Adultery & 1 & - & - & 1 & - & - \\
\hline 4 & Rape & 1 & 1 & - & 1 & 1 & - \\
\hline 5 & Pursue Underage Children & 2 & 5 & 3 & 2 & 5 & 3 \\
\hline
\end{tabular}

Source: Sat Reskrim Polres Kampar District

The number of cases of domestic violence that occurred in Kampar, would have an adverse impact on the development and protection of women, both as human (individual) and as a mother for the next generation, while the impact arising from the occurrence of domestic violence, especially against the wife are:

1. Usually have feelings of inferiority, shame and passivity;

2. Mental health disorders such as excessive anxiety, hard to eat and hard to sleep

3. Having serious illness, serious injury and permanent disability;

4. Sexual health disorders.

The magnitude of the negative impact of domestic violence on women is a common problem of the nation. Moreover, the impact of violence that is psychic, requires a long period of healing and broad impact. This is because women's natures as mothers and early educators for the sons of their daughters, so women must be physically and mentally healthy, while women affected by psychic violence will be mentally disturbed, and a necessity will be able to produce the next generation of healthy and intelligent people. Given the dangers of domestic violence for the sustainability of a nation, it is necessary to have concrete efforts by the government or stakeholders to prevent domestic violence against women from happening again, or in the event of a victimized woman not feeling ashamed to report.

Domestic violence is violence that has a unique character, because it occurs within the private sphere, the perpetrator is the closest person who should be the protector of the victim, and has a profound impact on the protection of everyone's human rights. As a State of Law with an obligation to protect the human rights of its citizens, the government has issued various policies and regulations to prevent domestic violence, including the issuance of Law Number 23 Year 2004 on the Elimination of Domestic Violence. But it is not very effective to suppress this violence, because of the high number of domestic violence, including in Riau Province. 
Furthermore, based on data in the last 3 (three) years following the recapitulation of the number of cases of violence against women and children in P2TP2A Kampar District, are:

Table 2. Recapitulation of Number of Violence Cases in Women and Children In P2TP2A Kampar District

\begin{tabular}{|l|l|l|l|l|l|l|l|l|}
\hline \multirow{2}{*}{ No } & \multirow{2}{*}{ Type of Case } & \multicolumn{3}{l}{ Number of Complaints } & \multicolumn{3}{l}{ Number of Complaints } \\
& & & \multicolumn{2}{l}{ Under the Follow up } \\
\cline { 3 - 9 } & & 2014 & 2015 & 2016 & 2014 & 2015 & 2016 \\
\hline 1 & Rape & 2 & - & 1 & 2 & - & 1 \\
\hline 2 & Fornication & 8 & 13 & 6 & 8 & 13 & 6 \\
\hline 3 & Child Abuse Persecution & 6 & 3 & 1 & 6 & 3 & 1 \\
\hline 4 & Persecution & - & 1 & - & - & 1 & - \\
\hline 5 & Domestic Violence & 2 & 7 & - & 2 & 7 & - \\
\hline 6 & Violence Against Children & 1 & 1 & - & 1 & 1 & - \\
\hline 7 & Coercion of Child Marriage & - & 1 & - & - & 1 & - \\
\hline 8 & Sexual harassment & - & 3 & - & - & 3 & - \\
\hline 9 & Fight & - & 1 & - & - & 1 & - \\
\hline 10 & Pursue Children under Age & - & 5 & 1 & - & 5 & 1 \\
\hline 11 & Theft & - & 8 & 5 & - & 8 & 5 \\
\hline
\end{tabular}

Source: P2TP2A Kampar District

Situations related to domestic violence, certainly still many who have not reported, or have reported but re-withdraw the report. This is because women are regarded as male subordination, the stereotyping of stereotyped roles, coupled with traditional female attitudes such as social and economic dependence on husbands and families and the fear and reluctance of women victims of violence to obtain justice, are the main causes between other causes that cause violence in the household is not revealed or not addressed. Traditional attitudes that assume that what happens in the household are the things that should be resolved in the household as well.

In addition to the limitations of legislation that can be used to resolve domestic violence through legal channels, from the convoluted reporting process, investigation and investigation process and court application, and court proceedings, -which is why not many victims complain to law enforcement. Still the scarcity of women's crisis centers and the victims' ignorance about the institutions that can help her solve her problems is also the reason that the victim chose to silence her.

One of the victims of domestic violence in Kampar regency said the factors causing domestic violence are based on several reasons such as:

1. Economic factors;

2. Factors of physical difference, power, and power. 
Economic factors are motivated because of the dependency of the wife to the husband, the wife does not have the skills to make money, so just accept the husband's rough treatment for fear of not being supported or afraid of divorce. Other factors are the domination of power by husbands and gender discrimination. The husband plays a full role in the family by ignoring the rights of his wife and children. The differentiation of roles and positions between husband and wife in society is culturally derived on every generation, even believed to be a religious provision. This resulted in the husband being placed as a person who has a higher power than the wife. Misinterpretation of religious values is exacerbating the occurrence of domestic violence.

UU PKDRT in passing has been comprehensive in preventing Domestic Violence. The imposition of sanctions for perpetrators of domestic violence is very heavy, compared with the imposition of sanctions in the Criminal Code. But in practice, the law enforcement process is still not running as expected. The most important inhibiting factor is not yet understood by the public against the dangers and effects of domestic violence, as it is isolated by patriarchal cultural values and a false understanding of religious texts. Similarly, in terms of victims / potential victims of systemic factors that cause it. Among the causes are poverty / economic factors, low education level, female mindset itself in view of its position, environmental factors, and many other factors.

Legal protection of women victims of domestic violence and their families requires a strong commitment with high regard for the value of justice, non-discrimination and human rights as guaranteed by the constitution.

The existence of a legal system that is not friendly with domestic violence cases is not solely because of the content of the law, but more on the mindset of law enforcement officers, government apparatus, and the wider community that is still surrounded by a patriarchal view so that discriminatory acts often color in daily life -day as evidence of domestic violence occurs in society. The move towards a gender-responsive legal system still needs a hard struggle through solving the root causes.

The problems studied are, firstly, how the implementation of women's empowerment policy in combating domestic violence in Kampar regency; second, what is the obstacle factor in implementing the policy of women empowerment in overcoming domestic violence in Kampar regency. Third, what is the ideal form to implement the policy of women empowerment in overcoming domestic violence in Kampar Regency in the future.

\section{Method}

The methods used in this research are:

1. Location and Time of Research Field research was conducted in Kampar District. Secondary data was collected at the library of the Faculty of Law, University of Riau, Soeman HS Regional Library, Pekanbaru Municipal Library, The study time was 6 (six) months.

2. How to Size Size Determination Sampling method is Purposive Sampling that is retrieval tailored to the purpose of research, the sample size is not questioned, the sample taken only in accordance with the purpose of the study. To achieve the purpose and purpose of this study, then the population and sample in this study are: 


\begin{tabular}{|l|l|l|l|l|}
\hline No & Respondents & Population & Sample & Percentage \\
\hline 1. & $\begin{array}{l}\text { Head of Law Department Setda } \\
\text { Kampar }\end{array}$ & 1 & 1 & $100 \%$ \\
\hline 2 & $\begin{array}{l}\text { Head of P2TP2A Kampar / } \\
\text { Department of Women } \\
\text { Empowerment and Child } \\
\text { Protection }\end{array}$ & 6 & 6 & $100 \%$ \\
\hline 4 & Kampar parliament & 4 & 4 & $100 \%$ \\
\hline 5 & Kampar District Police & 2 & 2 & $100 \%$ \\
\hline 6 & Society & 20 & 20 & $100 \%$ \\
\hline
\end{tabular}

3. Types and Data Sources: a. This type of research is sociological juridical with emphasis on field research. The sociological juridical approach is carried out because the problem studied revolves around how the application of law in society. Judging from its nature, this research is descriptive, because it intends to describe the facts examined clearly and systematically; b. Data source Data to be used in this research is:

1) Primary data is data obtained directly from the respondents by using data collection tools in the form of interviews;

2) Secondary data is data obtained from legislation, namely Law Number 23 Year 2004 on PKDRT, CEDAW, and the literature related to the main problem of this research;

3) Tertiary data is data obtained through dictionaries, encyclopedias, and the like to support both primary and secondary data.

4. Data Collection Techniques In accordance with the research stage, then the data obtained by technic:

a. Study Document in the form of research results, and literature that have relevance to the object of research.

b. Interviews, namely to the parties deemed competent and authorized in answering the problem of implementation of women's empowerment policy in overcoming domestic violence in Kampar District, consist of Kampar Regency Government, Kampar DPRD, P2TP2A, Kampar Society.

5. Data Analysis

The data obtained through this study were analyzed using qualitative juridical methods, looking for living and unwritten laws. Rules that one with the other should not be contradictory, pay attention to hierarchy of legislation and legal certainty.

\section{Discussion}

\subsection{Implementation of women's empowerment policy in combating domestic violence in Kampar District}

At a time when the culture of the nations is still low-grade, the law arises spontaneously unnoticed by the people. And as the culture develops, all the functions of society are entrusted 
to a certain group. Thus legal processing is entrusted to the jurists as experts in their fields, and thanks to the activities of them the rule of law can be built scientifically, technically, even though the legal development is still bound to the spirit of the living law in the soul of society or nation. Regarding the linkage of the nation's beliefs, Von Savigny named the political element and on the concept of technical processing he named it with technical elements. Therefore, the government at both central and local levels in issuing policies should be guided by the values that live in society.

Law Number 23 Year 2004 on the Elimination of Domestic Violence, is one of the legal products established by the government to implement the protection of human rights in private areas, especially in the form of domestic violence. This is in accordance with the mandate of the 1945 Constitution of the State of the Republic of Indonesia, especially Article $28 \mathrm{H}$ paragraph (2), namely the right to obtain convenience and special treatment in order to achieve equality and fairness (Affirmative Action), this is a legal breakthrough where originally domestic violence is considered as territory a private that no one outside the home environment can enter.

As a public law in which there is a threat of imprisonment or a fine for those who violate it, it is appropriate that the people comply with Law No. 23 of 2014 on PKDRT, with the awareness that this legal product is made by the government to protect the basic rights of the citizens for the sake of the realization of protection Human rights for all citizens as the demands of a state law (Rechsstaat).

The background of the presence of this Act is intended to provide a deterrent effect for the perpetrators of domestic violence, the threat of punishment that does not include a minimum penalty and only the maximum penalty so that the alternative legal threat of confinement or fines feels too light when compared with the impact received by the victim, even more profitable if using legal provisions as stipulated in the Criminal Code. In the implementation of this Act, there needs to be a strategic effort outside the victim's self in order to support and provide protection for the victims in order to disclose cases of domestic violence that befall them.

The scope of Law Number 23 Year 2004 on the Elimination of Domestic Violence, not only addressed to a husband, but also can be addressed to a wife who committed violence against her husband, her children, her family or her housemaid residing in a household.

The impact of Law Number 23 Year 2004 on Elimination of Domestic Violence in Indonesia each year is fluctuating, including in Kampar regency of Riau Province. This can be seen from the data of the number of rapes of domestic violence cases that researchers get from Kampar Polres from 2013-2016.

Based on these data provide an illustration to the authors that the lack of public awareness of the presence of Law Number 23 Year 2004 on Elimination of Domestic Violence in Kampar District. Various policies have been issued by the Local Government of Kampar Regency, among others are drafting the Local Regulation on the protection of women, making UP2K program (effort of increasing family income) in each sub-district, various training for housewife, and forming KTP women) in each sub-district.

Based on data that researchers get from some communities in Kampar district, said that some policies made by the Kampar regency government have not had a long-term impact on the empowerment of women victims of domestic violence, such as trainings that are conducted only temporarily and there is no continuation.

This shows that the implementation of women's empowerment policy in domestic violence prevention has not been maximized. The policy of domestic violence should be comprehensive and sustainable, there must be a complete and appropriate regulation 
accompanied by empowerment so not only protection of women. This is because most factors of domestic violence are economic factors, which in Kampar regency is divided into; low education, no permanent job, large number of family members in one house, early marriage and lack of religious understanding.

So it needs a policy of protection and empowerment of women victims of domestic violence in the form of Regional Regulations which also include empowerment in the economic sector, in accordance with the characteristics of local wisdom kampar community. Such as empowerment in the field of pineapple industry, salai patin, convection industry, and other economic sectors that exist in Kampar society.

\subsection{Factors inhibiting the Implementation of Women's Empowerment Policy in Preventing Domestic Violence in Kampar District}

Many challenges faced by Kampar regency government in the implementation of Law Number 23 Year 2004 on Elimination of Domestic Violence, namely:

1. Conventional Thinking Patterns In building a pattern of awareness of the existence of society as the subject of law, because most people in Kampar regency still faithful to conventional thinking patterns. The conventional pattern of thought is a way of thinking that sees the domestic realm as a private authoritarian territory, so that public law is deemed incapable of interfering with whatever happens within it. There are many cases of domestic violence, but local governments have difficulty handling because many women victims do not report.

2. Patriliakat Culture

The overwhelming majority of Muslim occupation, misinterpretation of religion and culture and cultural values in Kampar's social fabric, so that married women, thinking that it is their duty to guard every family's disgrace, the husbands' disgrace and feel legitimate what about what the husband did to him. This culture also places men as superiority in various fields, including in the household.

3. Lack of Socialization of Local Government Policy

The lack of socialization of the policies of Kampar regency government related to prevention of domestic violence in the form of trainings for housewives to improve their economy. So much of the training is not known to the public and is only temporary and there is no continuity.

4. No Legal Devices

Structurally there is no legal tool that is specifically used as legal reference at the regional level. There needs to be a Regional Regulation that provides comprehensive protection for victims of domestic violence.

\subsection{Ideal Form of Implementation of Women Empowerment Policy in Combating Domestic Violence In Kampar District}

The strengthening of efforts to eliminate violence against women through a structural approach must be done, so that public policies can become more responsive to women's conditions and positions. The notion of violence against women is not a question arising from individual elements, but rather systemic and structural.

In Law Number 23 Year 2004 regarding Elimination of Domestic Violence, the Government has obligations, namely: 
a. Formulate policies on abolishing domestic violence;

b. Organizing communication, information and education about domestic violence;

c. Organizing socialization and advocacy on domestic violence; and

d. Conduct gender sensitive education and training, and domestic violence issues and set gender-sensitive standards and service accreditation.

Based on the research data, Kampar District Government has issued many policies to prevent domestic violence, such as in the form of training for housewife in order to improve skill to earn a living, to form a task force of domestic violence, to make UP2K program (effort of improvement family income) in each sub-district. This year there are already Ranperda about the protection of women.

Law Number 23 Year 2004 on the Elimination of Domestic Violence is used as reference by the Regional Government officials of Kabupaten Kampar in the making of regional level policies aimed at protecting women. In a State of Law a law or law instrument is required to protect the rights of citizens. The legal product should be comprehensive. To protect the right of women in the prevention of domestic violence, ideally it should be in the form of empowerment so not just protection.

The understanding of the law further elaborated by Von Savigny is related to the concept of the state, namely that there is no individual human being. This is because every human being is part of a higher unity, family, nation, and country. Furthermore, he also reveals that every period weaves with the past, so that culture with law can only come from the soul of the nation, because the nation still holds its relationship with the past. Based on the understanding outlined by Von Savigny it would seem that law is a free human creation, but the free man is not an individual human being. In other words, the law does not come from an individual, who may be arbitrary, but derives from the soul of a nation closely interwoven with history.

So as to prevent the occurrence of domestic violence in Kampar regency, local government must make a policy to implement Law Number 23 Year 2004 about PKDRT, in the form of Local Regulation that match with characteristic of local people's economy. It aims at empowering women victims of domestic violence, through activities that are not foreign to them, so it will be more effective to be done. The ideal form of implementation of women's empowerment policy in the prevention of domestic violence in Kampar regency is in the form of Local Regulation on Protection and Empowerment of Domestic Violence Victims in the sectors of the people's economy in accordance with the local wisdom of the Kampar community, consisting mainly of: Pineapple industry, Salai Patin and Convection Industry. This is in line with Von Savigny's opinion that the law is the soul of the nation, which continues to grow but cannot be separated from its history.

\section{Conclusion}

1. Implementation of women's empowerment policy in prevention of Domestic Violence in Kampar Regency is not maximal, due to lack of regulations which regulate the protection and at the same time empower woman in economy sector which resulted in the lack of protection of women's rights of domestic violence victims. State through Kampar regency government should be more active role to carry out the mandate of this Law of PKDRT. The Law on Domestic Violence (PKDRT) explicitly states that domestic violence is a form 
of crime against human rights. The protection of human rights is an obligation in a State of Law and it is the responsibility of the government to exercise it both de jure and de facto;

2. The inhibiting factor of the implementation of women's empowerment policy in the prevention of domestic violence in Kampar regency is to lie in the cultural factor of society that is conventional thinking pattern which still strong with patriarchal culture, that men have higher social strata of women. Women or wives should obey or accept whatever treatment from men or husbands for the honor of the home, even at the expense of their basic rights. The excesses of this cultural factor, too, resulted in a less intense socialization of this Act, because the notion that domestic violence is a private / family matter is not considered important;

3. The ideal form of implementation of women's empowerment policy in the prevention of domestic violence in Kampar regency is to make the law in the form of regional regulation which not only regulate the protection but also the empowerment of women in social economy sector in accordance with the local wisdom of kampar regency society, women are economic factors.

Suggestions that writer can give in this research are:

Regulations are required in the form of legal products of the Regional Regulations, which regulate the protection of women and yet at the same time regulate the empowerment of women in the economic sector based on local wisdom of Kampar people. This will be a new breakthrough to change the legal system that does not have a gender perspective to be gender perspective as well as an effort to empower women to prevent domestic violence.

Because one of the obstacles to the implementation of UU PKDRT is community culture, it is expected to the Kampar Regency Government to include material on Gender understanding in formal and non-formal education system.

\section{References}

[1]. Endang Sutrisno - Hanari Fajarini, Legal Culture Of Pharmacist In The Perspective Of Pharmaceutical Services Standard In Pharmacies, Jurnal Dinamika Hukum Faculty Of Law Universitas Jenderal Soedirman Purwokerto, Vol.16. No. 2 May 2016, Page.152

[2]. Endang Sutrisno, Relations Between Legal Culture And Economic Empowerment Among Marginalized Group Of Farmers, Journal Of Legal, Ethical And Regulatory Issues, Volume 22, Issue 3, June 2019, Page 22-3-329.

[3]. Endang Sutrisno - Hanari Fajarini, Legal Culture Of Pharmacist In The Perspective Of Pharmaceutical Services Standard In Pharmacies, Jurnal Dinamika Hukum Faculty Of Law Universitas Jenderal Soedirman Purwokerto, Vol.16. No. 2 May 2016, Page.151.

[4]. Felix, S. (2009). Development Of Contract Legal Principles In Business Practices Over The Last 25 Years, Paper Presented At A Scientific Meeting At Bphn Dep. Justice, February 18-19.

[5]. Ihromi, Tapi Omas Dkk(Ed). (2006) Penghapusan Diskriminasi Terhadap Wanita. Bandung. Pt Alumni.

[6]. Johanes, G. (1994). Responsibilities Of Business Act No. 8 Of 1999 Concerning Consumer Consumers, Journal Of Business Law, 8.

[7]. Law Number 10 Of 1998 Concerning Banking Civil Law Act (Burgelijk Wetboek)

[8]. Law Number 8 Of 1999 Concerning Consumer Protection

[9]. Sutrisno, E., \& Jazilah, I. (2019). The Licensing Policy For Groundwater Extraction And Management For Hospitality Industry In Cities In Developing Countries. Water Policy. Https://Doi.Org/10.2166/Wp.2019.087 